\title{
WHO REACTS TO INCOME TAX RATE CHANGES? \\ THE RELATIONSHIP BETWEEN INCOME TAXES AND THE MOTIVATION TO WORK: THE CASE OF AZERBAIJAN
}

\author{
Orkhan Nadirov, Bruce Dehning, Khatai Aliyev, Minura Iskandarova
}

\begin{abstract}
This research investigates the effects of income taxation on the motivation to work by employing a survey method for the Azerbaijan population. The two research questions of interest are, if subjects consider income taxes when deciding how many hours to work and how subjects would react to a hypothetical 5\% income tax rate increase. Also examined are the responses to these questions between subjects with different socio-economic characteristics. Examining cross-sectional data of 326 respondents reveals that income taxes do not influence Azerbaijan labour market participants' motivation to work, regardless of their socio-economic characteristics. Empirical results indicate that reactions to hypothetical income tax rate increases show that the strength of response differs significantly across gender, age, marital status, field of employment, and income level. However, there are no significant results for differences in gender and after-tax wages. Our study contributes to the labour supply literature with the theory that after an income tax is imposed, both the average price and the average utility of leisure is greater for high wage earners than low wage earners.
\end{abstract}

The document can be downloaded at http://hdl.handle.net/10195/67936.

Keywords: Income taxes, Motivation to work, Survey design, OLS method, Azerbaijan.

JEL Classification: H24, J22.

\section{Introduction}

Most economists have accepted the notion that high income tax rates severely reduce the motivation to work for many years. Prior studies on the subject of income taxes and the motivation to work have been predominantly theoretical (Pigou,1929). According to the early hypothesis of Knight (1921), the motivation to work increases after direct income taxes are imposed or increased, in order to overcome the decline in after-tax income. However, Robbins (1997) and Cooper (1952) expand the theoretical formulation of this problem and assert that it is not possible, a priori, to measure the effect of a direct income tax on leisure and the motivation to work. They suggest that a direct income tax might have negative, positive or no effect on the work-leisure relationship and empirical measurements are needed to predict each direction. These formal treatments refer to the choice between leisure and income when they test the effect of income taxes on the motivation to work (Wald, 1945; Black, 1965; Henderson, 1948). But Rolph and Break (1961) touched upon a more comprehensive review of the theoretical reasoning related to income taxes and the motivation to work. Theory that stems from the neoclassical economic perspective defines the two ways in which income taxes may affect the motivation to work, the income effect and the substitution effect. The substitution effect is the decision a labourer makes when considering the price of an hour of leisure. The income effect is the decision a labourer makes when considering the number of hours of work required to maintain their level of income. 
In prior studies, economists refer to the price of leisure because they are considering the price to be the opportunity cost of leisure compared to the alternative of working. For instance, Goode (1949), Rolfe and Furness (1957), Break (1957), Musgrave (1959), Rolph and Break (1961), Fields and Stanbury (1971) and Robbins (1997) stated in their studies that the imposition of an income tax or increase in the tax rate is equal to a drop in the price of leisure. The income effect is straightforward, which moves people to do extra work to bring back their preceding level of disposable income. Income taxes make people feel poorer and leisure is a normal good, which means that workers prefer to consume less of it when they are poorer. But the substitution effect has an opposite effect that moves people to do less work because of a decline in the price of leisure. As a result, people feel compelled to take more time off since it will cost them less in forgone income. On the other hand, the income effect is less clear and its effect depends on government services producing a form of income for them. If the government services are satisfactory for taxpayers, then the income effect of income taxes is reduced and vice versa. If it is not satisfactory for taxpayers, their net wage would be reduced and taxes will have an income effect. For this reason, the substitution effect becomes comparatively more significant. Moreover, the impact of income taxes on the motivation to work cannot be defined by theorizing alone, because theory cannot explain the net effect of income taxes on the motivation to work. In one direction, the motivation to work is reduced if the substitution effect dominates income effect. In the other direction, the motivation to work is increased if the income effect is larger than the substitution effect. Which effect is stronger is an empirical question that must be resolved by empirical analysis rather than theoretical analysis (Cooper, 1952).

Various methodologies and different types of populations have been used in previous studies. For example, these include the study of 160 American business executives by Sander (1951), the survey of 1,429 British industrial workers carried out by the Prest (1956), the study of 1,000 German businessmen and professionals by Strümpel (1966) and a more sophisticated study of almost a thousand affluent Americans by Barlow et al. (1966). All of these studies have concluded that income taxes have minor disincentive effects on the motivation to work. In addition, Break (1957) attempted to measure the effects of high marginal rates of personal income taxes on the motivation to work of 306 British solicitors and accountants that are free to change their work incentives and are more informed about their marginal tax rates than most individuals are. In addition, he found that income taxes have little effect on the motivation to work.

After Break's study, Rolfe and Furness (1957), Chatterjee and Robinson (1969) tested the same relationship, but none of them found anything to contradict Break's earlier results. Fields and Stanbury (1971) used the same systematic approach employed by Break (1957). Fields and Stanbury (1971) interviewed 285 British solicitors and accountants in their study. They provided results similar to Break (1957). The main problem with these survey studies (e.g. Break, 1957; Fields and Stanbury, 1971) is that they have relied primarily on middleclass respondents. The study of 2000 weekly-paid workers by Brown and Levin (1974) was the first large survey that relied on responses from other socio-economic groups. They found that $74 \%$ of the men and $93 \%$ of the women stated that income taxes had no effect on the motivation to work. Afterwards, Brown et al. (1986) used simulation models based on very large-scale survey to estimate the effects of various tax changes on the motivation to work. They found that most individual's motivation to work is unresponsive to tax changes. 
Calderwood and Webley (1992) attempted to characterise the respondents whose motivation to work is responsive to taxes. They showed that income taxation is not salient for the most people in the UK. They stated that 31 persons out of 74 would work more if the tax rate increased, but the rest would work the same or less. However, their study was limited only to the employed persons. There is a notion that gender influences change in motivation to work due to tax rate changes. The argument is that men increase and women decrease their motivation to work when there is an increase in the income tax rate (Leuthold, 1983; James, 1992). More recent studies such as Eissa et al. (2008), Meghir and Phillips (2010), Keane (2011), and Saez et al. (2012) analyse differences in men and women's motivation to work. Their findings are similar to the results of previous studies that taxes increases men's motivation to work, but women's motivation to work is decreased by the prospect of their earnings being taxed. On the other hand, Manski (2014) concludes that we really do not know how the motivation to work responds to income tax rates. As a result, little is known about the effect of income taxes on all class respondents such as low, middle and high-income earners, and our study tries to go some way towards dealing with this ambiguity. However, elementary economic theory (substitution and income effects) might not apply in real life, because in reality income tax rates for low wage earners do not change, while high wage earners are affected. Contrary to prior economic-psychology approaches, our unique theory is the combination of the price of an hour of leisure, and also the utility of an hour of leisure, assuming it is higher for the high wage earners than the low wage earners (on average).

\section{Method}

\subsection{Subjects and Procedure}

Our target population was employed and unemployed persons in Azerbaijan. The survey was conducted in the form of online questionnaires between 1 July and 1 October 2016. The questionnaires were mailed to 1,330 people that were randomly selected with regard to gender, age, and their respective region of residence. There were 326 responses to the questionnaires, a response rate of $24.5 \%$. However, 19 questionnaires were not useable, resulting in $23 \%$ final response rate. The age of participants ranges from 18-65 with a mean of 28.9 years (std dev $=7.67$ ). Approximately $42 \%$ of the sample is female. The majority of subjects have an after-tax wage of below 500 AZN per month (52\%) compared to participants in higher income categories (500-1000 AZN: 33\%; above 1000 AZN: 15\%).

\subsection{Questionnaire, data description and analysis}

The questionnaire was divided into three parts: (1) perception of income taxes, (2) reactions to tax rate changes and (3) socio-demographic characteristics. The first section investigates whether income taxes affect the respondent's motivation to work by using the approach of Hayo and Uhl (2015). Subjects were asked, "Does the tax burden usually matter when you determine extent and intensity of your work activities?". Based on the responses, the dummy variable Tax problem was coded 1 if income taxes affect the subject's motivation to work and 0 if income taxes do not affect the subject's motivation to work.

The second section involves a measure based on Calderwood and Webley (1992) to assess people's reactions to hypothetical tax rate changes. In our analysis, Tax_react captures the responses of the survey participants to a 5\% hypothetical increase in the income tax rate. Subjects were asked, "Suppose, it is announced tomorrow that income tax rates 
increased by $5 \%$ ". Its value varies between 0 for subjects strongly reducing the amount of work to 5 for subjects strongly increasing the amount that they work.

Responses from the final demographics section on socio-economic characteristics were captured in the following variables and employed in the empirical analysis:

- Female is a dummy variable to measure the differences due to gender status; Female equals 1 if the participant is female, and 0 otherwise.

- Age is the participant's age in years, and is included in the analysis to test the effects of age on the research questions.

- Married is a dummy variable that equals 1 if the participant is married, otherwise 0 .

- Fiancé is a dummy variable that equals 1 if the participant is engaged to be married, otherwise 0 .

- Single is a dummy variable that equals 1 if the respondent is not engaged and is not married or has not been married, and 0 otherwise. This variable is used as a base group to examine the response differences due to marital status.

- Academic is a dummy variable that equals 1 if the participant works in a position of mostly academic related activity, otherwise 0 .

- Other_prof is a dummy variable that equals 1 for subjects working in positions outside of academia that require professional skills, otherwise 0 .

- Ins_empl is a dummy variable that equals 1 for those who are not employed in positions that require professional skills, otherwise 0 . This variable is used as a base group to examine the response differences due to field of employment.

- Unemp is a dummy variable that equals 1 if the subject is unemployed, otherwise 0 .

- High income is a dummy variable that equals 1 if the after-tax income of the corresponding candidate is more than 1000 AZN per month, otherwise 0 .

- Middle_income is a dummy variable that equals 1 if the after-tax income of the participant is 500-1000 AZN per month, otherwise 0 .

- Low_income is a dummy variable that equals 1 if the after-tax income of the respondent is less than $500 \mathrm{AZN}$ per month, otherwise 0 . This variable is employed as a base group to examine the response differences due to income.

SPSS analytical tools were employed in all empirical tests. Multivariate regression analysis using Ordinary Least Squares (OLS) as well as Binary Logit and Binary Probit estimation was used on cross-sectional data for robustness checks. The econometric models are estimated with different dependent variables but the same combination of independent variables. The models can be specified mathematically as follows:

Tax_problem ${ }_{i}=\delta_{0}+\delta_{1} *$ female $+\delta_{2} * \log (\text { age })_{i}+\delta_{3} *$ married $+\delta_{4} *$ fiance +

$+\delta_{5} *$ academic $+\delta_{6} *$ other_prof $f_{i}+\delta_{7} *$ unemp $+\delta_{8} *$ high_income $+\delta_{9} *$ middle_income +

$+v_{i}$

Tax_react $t_{i}=\gamma_{0}+\gamma_{1} *$ female $+\gamma_{2} * \log (\text { age })_{i}+\gamma_{3} *$ married $+\gamma_{4} *$ fiance +

$+\gamma_{5} *$ academic $+\gamma_{6} *$ other_prof $f_{i}+\gamma_{7} *$ unemp $p_{i}+\gamma_{8} *$ high_income $+\gamma_{9} *$ middle_income +

$+v_{i}$ 
Here, $\delta$ and $\gamma$ represent regression coefficients, $i$ denotes the $i^{\text {th }}$ observation, $v_{i}$ and $v_{i}$ are error terms.

\section{Results}

\subsection{Descriptive statistics}

The empirical findings are presented according to the two research questions. The first one addresses if taxes affect subjects' motivation to work. The second one addresses a 5\% hypothetical income tax rate increase and whether it affects subjects' motivation to work. The survey results show that $65.4 \%$ of respondents do not consider taxes when making their working decisions, while $34.6 \%$ do (see Table 1). There were 306 useable responses to this question. These results confirm previous literature that finds that income taxes have only minor disincentive effects on the motivation to work (Sander, 1951; Prest, 1956; Strümpel, 1966; Barlow et al., 1966; Break, 1957; Rolfe and Furness, 1957; Chatterjee and Robinson, 1969; Fields and Stanbury, 1971; Brown and Levin, 1974; Brown et al., 1986; Hayo and Uhl, 2015).

Tab. 1: Do taxes have any influence on your working decisions? Whole sample group analysis.

\begin{tabular}{|l|c|c|c|c|}
\hline & Frequency & Percent & Standard error & Conf. interval \\
\hline No & 200 & 65.4 & 2.7 & {$[60.9,69.9]$} \\
\hline Yes & 106 & 34.6 & 2.7 & {$[30.1,39.1]$} \\
\hline Total & 306 & 100 & - & - \\
\hline
\end{tabular}

Meanwhile, 308 survey participants provided their reaction to a hypothetical $5 \%$ increase in income tax rates. Table 2 presents the overall response degree statistics (from strongly reduce labour supply to strongly increase labour supply).

Tab. 2: What would your reaction be to a $5 \%$ income tax rate increase? Whole sample group analysis.

\begin{tabular}{|l|c|c|c|c|}
\hline & Frequency & Percent & Standard error & Conf. interval \\
\hline Strongly reduce labour supply & 12 & 3.9 & 1.1 & {$[2.1,5.7]$} \\
\hline Reduce labour supply & 29 & 9.4 & 1.7 & {$[6.7,12.1]$} \\
\hline Unchanged & 178 & 57.8 & 2.8 & {$[53.2,62.4]$} \\
\hline Increase labour supply & 34 & 11.0 & 1.8 & {$[8.1,13.9]$} \\
\hline Highly increase labour supply & 40 & 13.0 & 1.9 & {$[9.9,16.2]$} \\
\hline Strongly increase labour supply & 15 & 4.9 & 1.2 & {$[2.9,6.9]$} \\
\hline Total & 308 & 100 & - & - \\
\hline
\end{tabular}

Source: Authors' own compilation

Both Table 1 and Table 2 imply the same conclusion for the overall group; Azerbaijan labour market participant are not very sensitive to taxes. The majority of the participants do not consider taxes when deciding how much to work. This is supported by Table 2, as $57.8 \%$ of the sample responded that their motivation to work would not change if income taxes increased by 5\%. Our results provide very strong support for the hypothetical situation of Calderwood and Webley (1992). This result, however, is for all subjects and the responsiveness may differ across socio-economic characteristics. Demographic information was collected to test the research questions across different socio-economic characteristics of the respondents. Table 3 tabulates overall descriptive outputs. 
Tab. 3: Do taxes have any influence on your working decisions? Socio-economic categorical analysis.

\begin{tabular}{|c|c|c|}
\hline & Yes & No \\
\hline \multicolumn{3}{|l|}{ According to gender } \\
\hline Male & $32.6 \%$ & $67.4 \%$ \\
\hline Female & $38.1 \%$ & $61.9 \%$ \\
\hline \multicolumn{3}{|c|}{ Pearson Chi-Square (p-value) $=0.321$} \\
\hline \multicolumn{3}{|c|}{ According to marital status } \\
\hline Married & $32.3 \%$ & $67.7 \%$ \\
\hline Fiancé & $36.8 \%$ & $63.2 \%$ \\
\hline Single & $36.8 \%$ & $63.2 \%$ \\
\hline \multicolumn{3}{|c|}{ Pearson Chi-Square (p-value) $=0.715$} \\
\hline \multicolumn{3}{|c|}{ According to after-tax wage category } \\
\hline High income & $33.3 \%$ & $66.7 \%$ \\
\hline Middle income & $37.6 \%$ & $62.4 \%$ \\
\hline Low income & $33.8 \%$ & $66.2 \%$ \\
\hline \multicolumn{3}{|c|}{ Pearson Chi-Square (p-value) $=0.803$} \\
\hline \multicolumn{3}{|c|}{ According to employment field } \\
\hline Academic & $37.5 \%$ & $62.5 \%$ \\
\hline Other professional & $31.0 \%$ & $69.0 \%$ \\
\hline Insignificantly employed & $32.1 \%$ & $67.9 \%$ \\
\hline Unemployed & $36.5 \%$ & $63.5 \%$ \\
\hline
\end{tabular}

Source: Authors' own compilation

Similarly, proportional distribution to the primary research questions across groups with different socio-economic characteristics confirms the unresponsiveness of workers to taxes in Azerbaijan. The majority of responses are 'No' irrespective of gender, marital status, income level, or industry. This implies that taxes are not part of decision making for working purposes. It is interesting that across all socio-economic categories, approximately the same proportion of participants do not consider taxes when deciding how much to work. Only around 31-37.5\% consider taxes when making decision on how much to work. Pearson Chi-Square p-values are also highly revealing. In all cases the value is greater than 0.05 , which means that there are no significant differences between the specified groups within each category.

How a 5\% hypothetical income tax rate increase affects the motivation to work of Azerbaijan labour force participants with different socio-economic characteristics is tabulated in Table 4.

Tab. 4: What would your reaction be to a $5 \%$ income tax rate increase?

Socio-economic categorical analysis.

\begin{tabular}{|c|c|c|c|}
\hline & Reduce labour supply & Unchanged & Increase labour supply \\
\hline \multicolumn{4}{|l|}{ According to gender } \\
\hline Male & $12.9 \%$ & $57.3 \%$ & $29.8 \%$ \\
\hline Female & $14.0 \%$ & $58.9 \%$ & $27.1 \%$ \\
\hline \multicolumn{4}{|l|}{ Pearson Chi-Square (p-value) $=0.871$} \\
\hline \multicolumn{4}{|l|}{ According to marital status } \\
\hline Married & $9.6 \%$ & $65.2 \%$ & $25.2 \%$ \\
\hline Fiancé & $5.3 \%$ & $42.1 \%$ & $52.6 \%$ \\
\hline Single & $17.1 \%$ & $53.9 \%$ & $28.9 \%$ \\
\hline \multicolumn{4}{|l|}{ Pearson Chi-Square ( $p$-value $)=0.029$} \\
\hline According to after-tax wage category & & & \\
\hline
\end{tabular}




\begin{tabular}{|c|c|c|c|}
\hline High income & $9.3 \%$ & $76.7 \%$ & $14.0 \%$ \\
\hline Middle income & $15.8 \%$ & $57.9 \%$ & $26.3 \%$ \\
\hline Low income & $13.2 \%$ & $52.6 \%$ & $34.2 \%$ \\
\hline \multicolumn{4}{|c|}{ Pearson Chi-Square $(p$-value) $=0.520$} \\
\hline \multicolumn{4}{|c|}{ According to employment field } \\
\hline Academic & $10.0 \%$ & $62.0 \%$ & $28.0 \%$ \\
\hline Other professional & $7.0 \%$ & $58.1 \%$ & $34.9 \%$ \\
\hline Insignificantly employed & $21.5 \%$ & $62.0 \%$ & $16.5 \%$ \\
\hline Unemployed & $13.5 \%$ & $47.3 \%$ & $39.2 \%$ \\
\hline
\end{tabular}

Source: Authors' own compilation

The response to a 5\% hypothetical tax rate increase does not differ significantly between genders (Pearson Chi-Square (p-value) > 0.05). For both genders, more than half of the respondents say that the increase will not affect how much they work. $12.9 \%$ of males said that the increase would reduce the amount that they work, while $29.8 \%$ said they would work more, with the remainder responding that there would be no change in the number of hours worked. $14 \%$ of females said that the increase would reduce the amount that they work, while $27.1 \%$ said they would work more, with the remainder responding that there would be no change in the number of hours worked.

The impact of a hypothetical 5\% income tax rate increase is significantly different depending on the subject's marital status (Pearson Chi-Square (p-value) $<0.05$ ). This is particularly true for respondents engaged to be married. Fiancé was the only sub-category where a majority of the respondents said they would increase the number of hours worked if taxes increased. The majority of married and single subjects said that there would not be any significant impact.

There was no significant difference in responses for subjects in different income categories (Pearson Chi-Square (p-value) > 0.05). Nevertheless, there is a trend in the results. As after-tax income level falls, the share of participants who claim that their labour supply will not change decreases, while the share of responses in favour of more labour supply increases.

Across employment field, there were significant differences in the response to a hypothetical 5\% tax rate increase (Pearson Chi-Square (p-value) >0.05). However, it is very difficult to interpret the differences by examining the proportions. It appears as though more professionals, working either in or outside of academia, will reduce their output less than non-professionals, while non-professionals are less likely to increase their labour supply. For all three groups the majority of respondents would work the same regardless of the tax rate increase. Additional empirical analysis might clarify some of these results.

\subsection{Empirical Results}

Estimation outputs for equation (1) and (2) are presented in Table 5 below. There are no statistically significant coefficients for equation (1), which supports the statistical analysis shown previously in Table 1 and Table 3 . Such output is straightforward and plausible. Income taxes do not impact the motivation to work of people in the Azerbaijan labour market. This is true across different socio-economic characteristics.

Before interpreting estimation results, it is noteworthy to mention that residuals for both models are tested for heteroscedasticity by employing ARCH and White tests, autocorrelation by using Breusch-Godfrey Serial Correlation LM Test, and functional misspecification problem with Ramsey-Reset test. Moreover, the Jarque-Bera test is applied 
to examine normality in the distribution of residuals. Test results show no heteroscedasticity, autocorrelation, or functional misspecification in equation (1) nor in equation (2) $(p .>0.10)$. In equation (2), test output indicates a normal distribution of residuals $(p .>0.10)$. For equation (1), the value of the Jarque-Bera test result is fairly high $\left(\mathrm{JB}_{\mathrm{N}}=39.13645\right)$, which means rejection of the null hypothesis $\left(H_{0}\right.$ : residuals are normally distributed) at $1 \%$ significance level $(p .<0.01)$. However, normal distribution of residuals is not a serious problem in large samples. As the sample size in equation (1) is fairly large (250), this shortcoming can be ignored.

\section{Tab. 5: Empirical results}

\begin{tabular}{|c|c|c|c|c|}
\hline \multirow[t]{2}{*}{ Independent variables } & \multicolumn{3}{|c|}{$\begin{array}{c}\text { Tax_problem } \\
\text { (equation 1) }\end{array}$} & \multirow[t]{2}{*}{$\begin{array}{c}\text { Tax_react } \\
\text { (equation 2) }\end{array}$} \\
\hline & $O L S$ & Logit & Probit & \\
\hline Female & $\begin{array}{c}0.0585 \\
(0.3702)\end{array}$ & $\begin{array}{c}0.2638 \\
(0.2898)\end{array}$ & $\begin{array}{c}0.1698 \\
(0.1777)\end{array}$ & $\begin{array}{l}-0.2560 * \\
(0.1471)\end{array}$ \\
\hline $\log ($ age $)$ & $\begin{array}{c}0.1161 \\
(0.4813) \\
\end{array}$ & $\begin{array}{c}0.5287 \\
(0.7261) \\
\end{array}$ & $\begin{array}{c}0.3258 \\
(0.4425) \\
\end{array}$ & $\begin{array}{c}-0.9791 * * * \\
(0.3657) \\
\end{array}$ \\
\hline Married & $\begin{array}{l}-0.0151 \\
(0.8563)\end{array}$ & $\begin{array}{l}-0.0696 \\
(0.3701)\end{array}$ & $\begin{array}{l}-0.0421 \\
(0.2264)\end{array}$ & $\begin{array}{c}0.2230 \\
(0.1859)\end{array}$ \\
\hline Fiancé & $\begin{array}{c}0.0616 \\
(0.6145) \\
\end{array}$ & $\begin{array}{c}0.2797 \\
(0.5307) \\
\end{array}$ & $\begin{array}{c}0.1728 \\
(0.3263) \\
\end{array}$ & $\begin{array}{c}0.7172 * * \\
(0.2767)\end{array}$ \\
\hline Academic & $\begin{array}{l}-0.0349 \\
(0.7140)\end{array}$ & $\begin{array}{l}-0.1527 \\
(0.4256)\end{array}$ & $\begin{array}{l}-0.0892 \\
(0.2599)\end{array}$ & $\begin{array}{c}0.2246 \\
(0.2138)\end{array}$ \\
\hline Other_professional & $\begin{array}{l}-0.0329 \\
(0.6527)\end{array}$ & $\begin{array}{l}-0.1474 \\
(0.3285)\end{array}$ & $\begin{array}{l}-0.0861 \\
(0.2008)\end{array}$ & $\begin{array}{c}0.4713 * * * \\
(0.1652)\end{array}$ \\
\hline Unemployed & $\begin{array}{c}0.1290 \\
(0.0696)\end{array}$ & $\begin{array}{c}0.5666 \\
(0.3085) \\
\end{array}$ & $\begin{array}{c}0.3512 \\
(0.1904) \\
\end{array}$ & $\begin{array}{l}-0.2229 \\
(0.1603) \\
\end{array}$ \\
\hline Middle_income & $\begin{array}{c}0.0996 \\
(0.1707)\end{array}$ & $\begin{array}{c}0.4439 \\
(0.3197) \\
\end{array}$ & $\begin{array}{c}0.2777 \\
(0.1962)\end{array}$ & $\begin{array}{l}-0.2154 \\
(0.1625)\end{array}$ \\
\hline High_income & $\begin{array}{c}0.0314 \\
(0.7485) \\
\end{array}$ & $\begin{array}{c}0.1421 \\
(0.4398) \\
\end{array}$ & $\begin{array}{c}0.0871 \\
(0.2679) \\
\end{array}$ & $\begin{array}{c}-0.5063 * * \\
(0.2213)\end{array}$ \\
\hline $\mathrm{C}$ & $\begin{array}{l}-0.1181 \\
(0.8230)\end{array}$ & $\begin{array}{l}-2.7592 \\
(2.3351)\end{array}$ & $\begin{array}{l}-1.7102 \\
(1.4227)\end{array}$ & $\begin{array}{c}5.5900 * * * \\
(1.1723)\end{array}$ \\
\hline $\mathrm{R}^{2}$ & 0.0281 & 0.0217 & 0.0220 & 0.1181 \\
\hline Included Obs. & 250 & 250 & 250 & 251 \\
\hline St. Error of regression & 0.4780 & 0.4784 & 0.4784 & 1.0816 \\
\hline \multicolumn{5}{|c|}{ Statistics and Residuals Diagnostics tests results } \\
\hline Equation 1 (OLS) & \multicolumn{4}{|c|}{$\begin{array}{l}\sigma=0.477986 ; \chi_{\mathrm{SC}}^{2}(2)=0.589780[0.5553] ; \chi_{\mathrm{ARCH}}^{2}(4)=1.517827[0.2054] ; \\
\quad \chi_{\mathrm{HETR}}^{2}=0.821921[0.7750] ; \mathrm{JB}_{\mathrm{N}}=39.13645[0.0000] ; \mathrm{F}_{\mathrm{FF}}=1.177992[0.3097]\end{array}$} \\
\hline Equation 2 & \multicolumn{4}{|c|}{$\begin{array}{l}\sigma=1.081646 ; \chi_{\mathrm{SC}}^{2}(2)=0.201762[0.8174] ; \chi_{\mathrm{ARCH}}^{2}(4)=0.224480[0.9239] ; \\
\quad \chi_{\mathrm{HETR}}^{2}=1.319861[0.1047] ; \mathrm{JB}_{\mathrm{N}}=2.659610[0.2654] ; \mathrm{F}_{\mathrm{FF}}=0.169034[0.8446]\end{array}$} \\
\hline \multicolumn{5}{|c|}{$\begin{array}{l}\text { Note: } \sigma \text { is standard error of regression; } \chi_{\mathrm{SC}}^{2}, \chi_{\mathrm{ARCH}}^{2} \text { and } \chi_{\mathrm{HETR}}^{2} \text { denote chi-squared statistics to test the null } \\
\text { hypotheses of no autocorrelation, no autoregressive conditioned heteroscedasticity, and no heteroscedasticity } \\
\text { (White test) in the residuals; } \mathrm{JB}_{\mathrm{N}} \text { indicate statistics to test the null hypotheses of normal distribution; } \\
*, * * \text { and } * * * \text { denote significance level of } 10 \%, 5 \% \text {, and } 1 \% \text { levels, respectively; Standard errors for each } \\
\text { coefficient are in (). Probabilities are in []. }\end{array}$} \\
\hline
\end{tabular}

Source: Authors' own compilation

Estimation results for equation (2) are highly valuable in helping evaluate the determining factors for labour supply response to a hypothetical 5\% income tax rate increase. The coefficient on the gender dummy variable, Female, is negative and significant $(p<.10)$. Females are much more sensitive to income tax changes and will reduce their work compared to males when faced with an income tax rate increase. These results are in line with previous studies that have reported that women are more sensitive than men are 
to income taxes (Leuthold, 1983; James, 1992; Eissa et al., 2008; Meghir and Phillips, 2010; Keane, 2011; Saez et al., 2012). Age is also a statistically significant factor $(\gamma=-.97, p<0.01)$. As age increases the motivation to work change of participants, on average, decreases significantly. However, if we look at the size of the coefficient, it seems to be economically insignificant. A $1 \%$ increase in age level decreases the motivation to work by only 0.0097 points on average.

The regression results for marital status are similar to the univariate results. Compared to single participants, married subjects' responses are not statistically significant. However, the impact of the tax rate increase is significantly higher for fiancé subjects' motivation to work $(\gamma=.71, p<0.05)$ compared to married and single subjects. Therefore, the research reveals that fiancés are more responsive to income tax rate increases.

Considering the employment status of the participants, empirical results provide no significant differences between academicians, non-professional, and unemployed subjects. Note that unemployed subjects also considered taxes more than others in their decisionmaking (equation 1), although this difference is not statistically significant. However, non-academic professionals' labour supply change response is significantly higher $(\gamma=.47, p<0.01)$ and positive. The overall conclusion is that only non-academic professionals are highly responsive to income tax rate changes.

In the labour supply literature, it is quite interesting how the motivation to work changes in response to income tax rate increases based on the after-tax wage category (Hausman, 1985). As shown in the univariate results, we observed a decline in the motivation to work as after-tax wages increase. Compared to low income participants, the middle-income group's response is higher, i.e., the coefficient is negative, but it is not statistically significant. In the high-income category we observe a negative and statistically significant difference $(\gamma=-.50, p<0.01)$ compared to lower income categories. This means that high-income participants are more sensitive to income tax rate increases than low-income participants are.

\section{Conclusion}

Economists primarily use three methodological approaches to studying the relationship between income taxes and the motivation to work: surveys of attitudes and perceived behaviour, laboratory experiments, and observed labour market behaviour through analysis of aggregate data (Atkinson and Stigliz, 2015; Lewis, 1982). Our approach is the study of attitude and perceived behaviour, where the most apparent congruence between economics and social psychology occurs. Directly questioning individuals about the effect of economic policy on their attitudes is unusual and nonstandard in economic fields. Therefore, using self-reported answers to tax changes helps us to make a diverse contribution to the literature on income taxes and the motivation to work. This research strategy allows policymakers to estimate the effects of income tax changes on labour markets with different socio-economic characteristics.

The first test was the extent to which the Azerbaijan population is sensitive to income taxes. Only around 35\% report taking income taxes into consideration, which shows that the majority of the Azerbaijan population is unresponsive to income taxes. The second test assesses reactions to a hypothetical income tax rate change. Around $57.8 \%$ of the sample responded that their motivation to work would not change if income tax rates increased by $5 \%$. 
Using our first research item (perception of income taxes), we find that responses do not vary across groups with different socio-economic characteristics such as gender, marital status, after-tax wage category, and employment field. Using the second research item (reactions to tax rate changes), we find that significant differences in the strength of responses to a hypothetical income tax rate change across gender, age, marital status (engaged), employment field (non-academic professionals), and after tax wages (high-income only).

Although this study is small in scale and limited to only two research questions and a few social-economic variables, future research can examine additional psychological and economic variables such as social services, welfare, attitudes towards work, the value placed on leisure time, the number of dependents, households with one instead of two working parents, non-labour income, etc. However, we believe that our conclusions have several implications for policy and decision-making. One of the strongest ideas is that after an income tax is imposed, both the price and utility of leisure are higher for the higher wage earners than for low wage earners (on average). Our theory is that as people make more money the utility of their leisure time goes up because they can spend the money they make to purchase activities with higher utility. Testing with a 5\% hypothetical income tax rate change, we found that higher wage earners in Azerbaijan will be more sensitive to this change and thus they will start to work less. This theory can be tested with the aggregate time series evidence (life-cycle models) to see also how tax policy shocks affect the motivation to work along with individual's saving decisions, human capital accumulation, and the history dependence in preferences (Keane, 2011). But, the difficulty of collecting empirical data on tax behaviour has led scholars to generate their own data with survey techniques (Kirchler, 2007). Consequently, using this research method in the future will allow us to determine whether increasing income tax rates can be salient in the daily lives of workers in Azerbaijan. To the best of our knowledge, little is known about the effect of tax rate changes on labourers' work motivation in poor and rich countries. For this reason, future research can test our theory with hypothetical tax rate changes for poor and rich countries with different economic and legal systems to see if there is a differences between the price and utility of leisure for higher and lower wage earners. Finally, the most popular hypothesis about women's motivation to work (more sensitive to taxation) and men's motivation to work (less sensitive to taxation) is supported by our data and empirical results for the Azerbaijan population.

\section{Acknowledgement}

The authors would like to thank the Internal Grant Agency of FaME for providing financial support to carry out this research. Funding was extended through: TBU No. IGA/FaME/2017/018 - "Income tax and motivation to work". Moreover, the authors would like to thank the participants in the $20^{\text {th }}$ European Scientific Conference of Doctoral Students PEFnet, especially to Danuše Nerudová and one anonymous reviewer.

\section{References}

Atkinson, A. B., Stiglitz, J. E. (2015). Lectures on public economics. Princeton University Press.

Barlow, R., et al. (1966). Economic behavior of the affluent.

Black, D. (1965). The incidence of income taxes. Taylor \& Francis.

Break, G. F. (1957). Income taxes and incentives to work: An empirical study. The American Economic Review, 47.5: 530-549. 
Brown, C. V., Levin, E. (1974). The effects of income taxation on overtime: The results of a national survey. The Economic Journal, 84.336: 833-848.

Brown, C. V., et al. and DT ULPH. (1986). Unemployment, search and labour supply, 190.

Calderwood, G., Webley, P. (1992). Who responds to changes in taxation? The relationship between taxation and incentive to work. Journal of Economic Psychology, 13.4: 735-748.

Chatterjee, A., Robinson, J. (1969). Effects of Personal Income Tax on Work Effort: A Sample Survey. Canadian Tax Journal, 17.3: 211-20.

Cooper, G. (1952). Taxation and incentive in mobilization. The Quarterly Journal of Economics, 66.1: 43-66.

Eissa, N., Kleven, H. J., Kreiner, C. T. (2008). Evaluation of four tax reforms in the United States: Labor supply and welfare effects for single mothers. Journal of Public Economics, 92.3: 795-816.

Fields, D. B., Stanbury, W. T. (1971). Income taxes and incentives to work: Some additional empirical evidence. The American Economic Review, 435-443.

Goode, R. (1949). The income tax and the supply of labor. Journal of Political Economy, 57.5: 428-437.

Hayo, B., Uhl, M. (2015). Taxation and labour supply: Evidence from a representative population survey. Journal of Macroeconomics, 45: 336-346.

Hausman, J. A. (1985). Taxes and labor supply. Handbook of public economics, 1: 213-263.

Henderson, A. (1948). The case for indirect taxation. The Economic Journal, 58.232: 538-553.

James, S. (1992). Taxation and female participation in the labour market. Journal of economic psychology, 13.4: $715-734$.

Keane, M. P. (2011). Labor supply and taxes: A survey. Journal of Economic Literature, 49.4: 961-1075.

Kirchler, E. (2007). The economic psychology of tax behaviour. Cambridge University Press.

Knight, F. H. (1921). Risk, uncertainty and profit. New York: Hart, Schaffner and Marx.

Lewis, A. (1982). The psychology of taxation. Blackwell.

Leuthold, J. H. (1983). Home production and the tax system. Journal of Economic Psychology, 3.2: 145-157.

Manski, CH. F. (2014). Identification of income-leisure preferences and evaluation of income tax policy. Quantitative Economics, 5.1: 145-174.

Meghir, C., Phillips, D. (2010). Labour supply and taxes. Dimensions of tax design: The Mirrlees Review, 202-74.

Musgrave, R. A. (1959). The theory of public finance. McGraw-Hill Book Company, Inc.

Pigou, A. C. (1929). The economics of welfare. Macmillan and Company, limited.

Prest, A. R. (1956). The Royal Commission on the Taxation of Profits and Income. Economica, 23.92: 366-374.

Rolph, E. R., Break, G. F. (1961). Public finance. Ronald Press Company.

Rolfe, S. E., Furness, G. (1957). The Impact of Changes in Tax Rates and Method of Collection on Effort: Some Empirical Observations. The Review of Economics and Statistics, 394-401.

Robbins, L. (1997). On the elasticity of demand for income in terms of effort. In: Economic Science and Political Economy. Palgrave Macmillan UK, p. 79-84.

Saez, E., Slemrod, J., Giertz, S. H. (2012). The elasticity of taxable income with respect to marginal tax rates: A critical review. Journal of economic literature, 50.1: 3-50.

Sanders, T. H. (1951). Effects of taxation: on executives. Harvard University Graduate School of Business Administration.

Strümpel, B. (1966). Steuermoral und Steuerwiderstand der deutschen Selbständigen: ein Beitrag zur Lehre von den Steuerwirkungen. Springer-Verlag. 
Wald, H. P. (1945). The classical indictment of indirect taxation. The Quarterly Journal of Economics, 59.4: 577-596.

\section{Contact Addresses}

\section{Orkhan Nadirov}

Tomas Bata University in Zlin University, Faculty of Management and Economics, Department of Finance and Accounting

Mostní 5139, 76001 Zlín, Czech Republic

Email: nadirov@fame.utb.cz

Phone number: +420776 831939

\section{Bruce Dehning}

Chapman University Argyros School of Business and Economics,

Orange, California, United States

Email: bdehning@chapman.edu

Phone number: (714) 628-2702

\section{Khatai Aliyev}

Baku Engineering University

Department of World Economy

Khirdalan city, Hasan Aliyev str. 120, Baku, Absheron, AZ0101, Azerbaijan;

Institute of Control Systems, Azerbaijan National Academy of Sciences, Baku, Azerbaijan Vahabzade Street 9, Baku AZ1141, Azerbaijan

Email: xaliyev@qu.edu.az

Phone number: +994 507831582

\section{Minura Iskandarova}

Baku Engineering University

Department of World Economy

Khirdalan city, Hasan Aliyev str. 120, Baku, Absheron, AZ0101, Azerbaijan;

Email: msiskandarova@gmail.com

Phone number: +994 517282659

Received: 31. 12. 2016, reviewed: 13. 02. 2017, 07. 03. 2017

Approved for publication: 20. 03. 2017 